\title{
ASSESSMENT OF STREAM QUALITY USING BIOLOGICAL INDICES AT SELECTED SITES IN THE RED CLAY AND WHITE CLAY CREEK BASINS, CHESTER COUNTY, PENNSYLVANIA, 1981-97
}

\section{INTRODUCTION}

In 1970, the Chester County Water Resources Authority (Pennsylvania) and the U.S. Geological Survey (USGS) established a longterm water-quality network with the goal of assessing the quality of streams in the county and understanding stream changes in response to urbanization using benthic-macroinvertebrate data (Lium, 1977). This database represents one of the longest continuous water-quality data sets in the country. Benthic macroinvertebrates are aquatic insects, such as mayflies, caddisflies, riffle beetles, and midges, and other invertebrates that live on the stream bottom. Benthic macroinvertebrates are useful in evaluating stream quality because their habitat preference and low motility cause them to be affected directly by substances that enter the aquatic system. By evaluating the diversity and community structure of benthic-macroinvertebrate populations, a determination of stream quality can be made.

Between 1981 and 1997, the water-quality network consisted of 43 sites in 5 major basins in Chester County-Delaware, Schuylkill, Brandywine, Big Elk and Octoraro, and Red and White Clay. Benthicmacroinvertebrate, water-chemistry, and habitat data were collected each year in October or November during base-flow conditions (Reif, 1999; 2000). Using these data, Reif (2002) evaluates the overall water-quality condition of Chester County streams. This Fact Sheet summarizes the key findings from Reif (2002) for streams in the Red

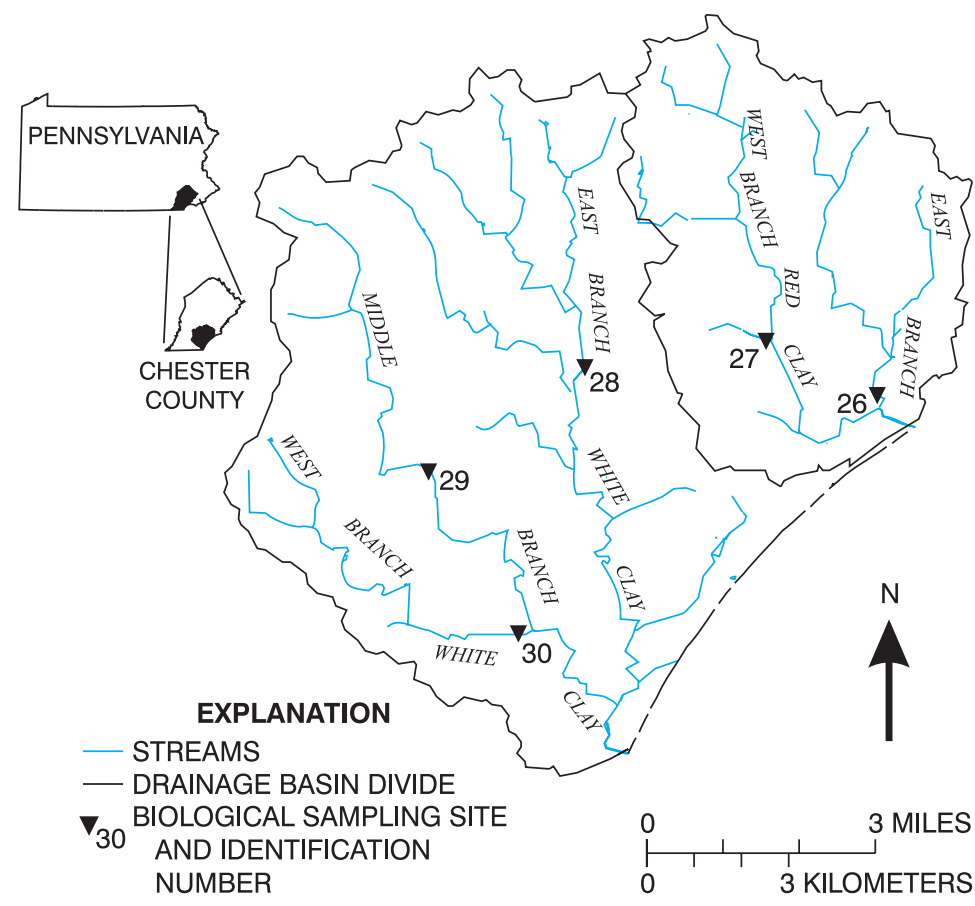

Figure 1. Location of sampling sites in the Red Clay and White Clay Creek Basins, Chester County, Pennsylvania.
Clay and White Clay Creek Basins. These streams include East Branch Red Clay Creek (site 26), West Branch Red Clay Creek (site 27), East Branch White Clay Creek (site 28), the Middle Branch White Clay Creek (site 29), and West Branch White Clay Creek (site 30) (fig. 1). This summary includes an analysis of stream conditions on the basis of benthic-macroinvertebrate samples and an analysis of trends in stream conditions for the 17-year study period.

\section{STUDY APPROACH}

The analysis of overall stream quality on the basis of benthicmacroinvertebrate sampling uses biological metrics. Each biological metric is a mathematical expression of a different aspect of the benthic-macroinvertebrate community and how it relates to overall stream quality. By examining each biological metric, an evaluation of the overall stream quality can be made. The following biological metrics were used in the analysis: taxa richness, Ephemeroptera, Plecoptera, and Trichoptera (EPT) taxa richness, percent EPT, and Hilsenhoff's biotic index (HBI).

Taxa richness is a measure of the number of different kinds of organisms (taxa) in a collection. Richness measures the overall diversity of the biological community sampled. EPT taxa richness is the total number of taxa within the "pollution sensitive" orders

Ephemeroptera (mayflies), Plecoptera (stoneflies), and Trichoptera (caddisflies). Taxa richness and EPT taxa richness will decrease with decreasing water quality (Weber, 1973). Percent EPT is the total number of EPT individuals divided by the total number of individuals in the sample.

The HBI is based on an organism's relative sensitivity to stream-quality conditions. The HBI uses assigned tolerance values that range from 0 to 10 . A 0 is assigned to organisms least tolerant of organic pollution, and a 10 is assigned to organisms most tolerant of organic pollution. Species intermediate in their tolerance of organic pollution were assigned intermediate values (Hilsenhoff, 1982). Tolerance values are from the genus and species-level biotic index developed by the State of New York (Bode, 1991). HBI values from 0 to 4.5 are associated with nonimpacted sites, 4.51 to 6.50 with slightly impacted sites, 6.51 to 8.50 with moderately impacted sites, and 8.51 to 10 with severely impacted sites (Bode, 1993).

\section{STREAM-QUALITY DESIGNATION CRITERIA}

Streams in the network were designated as nonimpacted, slightly impacted, moderately impacted, or severely impacted on the basis of median biological metric values from 1981 to 1997 (table 1). Stream-quality refers to the overall condition of the physical habitat, water chemistry, and biological communities in the stream.

Nonimpacted: Biological metrics indicate excellent stream quality. The benthic-macroinvertebrate community is diverse, and the community is dominated by "pollution sensitive" and facultative organisms. "Pollution sensitive" organisms include 
Table 1. Stream-quality assessment criteria for Chester County, Pennsylvania, streams (adapted from Bode, 1993) [EPT, Ephemeroptera, Plecoptera, and Trichoptera; HBI, Hilsenhoff's biotic index; >, greater than]

\begin{tabular}{lccc}
\hline $\begin{array}{c}\text { Stream-quality } \\
\text { assessment }\end{array}$ & $\begin{array}{c}\text { Taxa } \\
\text { richness }\end{array}$ & $\begin{array}{c}\text { EPT taxa } \\
\text { richness }\end{array}$ & HBI \\
\hline Nonimpacted & $>30$ & $>10$ & $0-4.50$ \\
Slightly impacted & $21-30$ & $6-10$ & $4.51-6.50$ \\
Moderately impacted & $11-20$ & $2-5$ & $6.51-8.50$ \\
Severely impacted & $0-10$ & $0-1$ & $8.51-10$ \\
\hline
\end{tabular}

the EPT taxa and generally are intolerant of degraded stream quality. Facultative organisms can survive under a wide range of stream conditions. Water-quality and habitat conditions at nonimpacted sites are not limiting the benthic-macroinvertebrate community. Nonimpacted sites include pristine habitats and those receiving inputs that minimally affect the benthic-macroinvertebrate community.

Slightly Impacted: Biological metrics indicate good stream quality. The benthic-macroinvertebrate community is less diverse than at nonimpacted sites but still contains mayflies, caddisflies, and possibly some stoneflies. The community structure typically is dominated by a few taxa including caddisflies, elmids (riffle beetles), and chironomids. Water-quality and habitat conditions are having an effect on the benthic-macroinvertebrate community. Slightly impacted sites commonly are receiving some wastewater inputs and (or) agricultural/urban runoff.

Moderately Impacted: Biological metrics indicate fair stream quality. The benthic-macroinvertebrate community is disturbed and noticeably altered from a nonimpacted site. Mayflies and stoneflies are rare, and caddisfly taxa may be limited. The benthic-macroinvertebrate community is dominated by "pollution tolerant" and facultative organisms including chironomids and oligochaetes (aquatic earthworms). One or a few groups usually dominate the community. Water quality and habitat conditions are having a major effect on the benthic-macroinvertebrate community. Moderately impacted sites commonly are receiving heavy wastewater inputs and (or) agricultural/urban runoff.

Severely Impacted: Biological metrics indicate poor stream quality. The benthic-macroinvertebrate community is severely limited with poor diversity. Mayflies, stoneflies, and caddisflies are rare, and the community usually is dominated by chironomids and aquatic earthworms. The community may have low numbers of individuals or

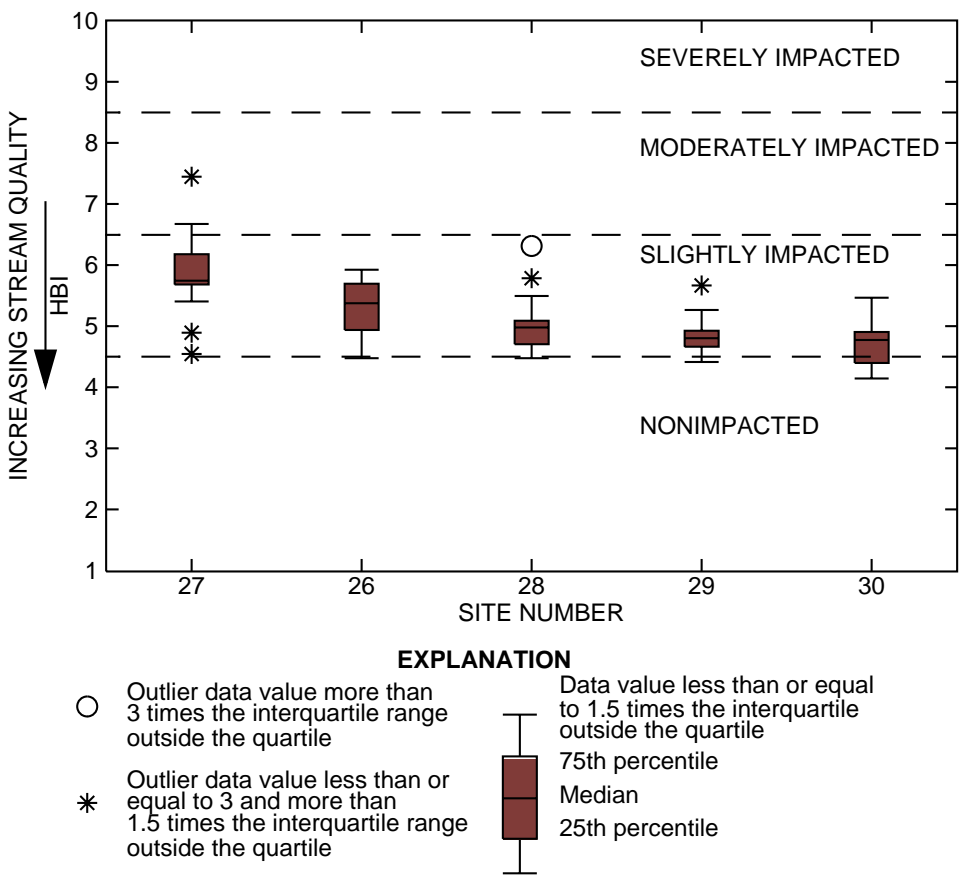

Figure 2. Hilsenhoff's biotic index (HBI) values from sites in the Red Clay and White Clay Creek Basins, Chester County, Pennsylvania, 1981-97.

high numbers of a few taxa. Severely impacted sites commonly are receiving inputs of a toxin or have extremely low concentrations (less than $4.0 \mathrm{mg} / \mathrm{L}$ ) of dissolved oxygen. Water-quality and habitat conditions are having a severe effect on the benthic-macroinvertebrate community. Severely impacted sites commonly are receiving heavy wastewater input, and agricultural/urban runoff.

\section{STREAM-QUALITY ASSESSMENT}

The five sampling sites in the Red Clay and White Clay Creek Basins each had a drainage area of approximately $10 \mathrm{mi}^{2}$ (square miles). Land use in both basins is a mix of agriculture, residential, and forested areas. Sites in the Red Clay Creek Basin (sites 26 and 27) also receive runoff from mushroom and compost facilities that are prevalent in the area. Stream-quality assessments based on calculated biological metrics are presented in table 2 and figure 2.

Table 2. Designation of water quality and median values of taxa richness, EPT taxa richness, Hilsenhoff's biotic index, and percent EPT for sites in the Red Clay and White Clay Creek Basins, Chester County, Pennsylvania, 1981-97

[EPT, Ephemeroptera, Plecoptera, and Trichoptera]

\begin{tabular}{|c|c|c|c|c|c|}
\hline $\begin{array}{c}\text { U.S. Geological } \\
\text { Survey station } \\
\text { identification number }\end{array}$ & $\begin{array}{c}\text { Site } \\
\text { number }\end{array}$ & Taxa richness & $\begin{array}{l}\text { EPT taxa } \\
\text { richness }\end{array}$ & $\begin{array}{l}\text { Hilsenhoff's } \\
\text { biotic index }\end{array}$ & $\begin{array}{c}\text { Percent } \\
\text { EPT }\end{array}$ \\
\hline \multicolumn{6}{|c|}{ West Branch Red Clay Creek } \\
\hline 01479680 & 27 & $\begin{array}{l}\text { Moderately impacted } \\
15\end{array}$ & $\begin{array}{c}\text { Moderately impacted } \\
3\end{array}$ & $\begin{array}{c}\text { Slightly impacted } \\
5.75\end{array}$ & 4 \\
\hline \multicolumn{6}{|c|}{ East Branch Red Clay Creek } \\
\hline 01479800 & 26 & $\begin{array}{l}\text { Moderately impacted } \\
\qquad 17\end{array}$ & $\begin{array}{c}\text { Moderately impacted } \\
3\end{array}$ & $\begin{array}{c}\text { Slightly impacted } \\
5.38\end{array}$ & 2 \\
\hline \multicolumn{6}{|c|}{ East Branch White Clay Creek } \\
\hline 01478120 & 28 & $\begin{array}{c}\text { Slightly impacted } \\
21\end{array}$ & $\begin{array}{c}\text { Slightly impacted } \\
10\end{array}$ & $\begin{array}{c}\text { Slightly impacted } \\
4.98\end{array}$ & 29 \\
\hline \multicolumn{6}{|c|}{ Middle Branch White Clay Creek } \\
\hline 01478190 & 29 & $\begin{array}{l}\text { Slightly impacted } \\
24\end{array}$ & $\begin{array}{c}\text { Nonimpacted } \\
12\end{array}$ & $\begin{array}{c}\text { Slightly impacted } \\
4.81\end{array}$ & 52 \\
\hline \multicolumn{6}{|c|}{ West Branch White Clay Creek } \\
\hline 01478220 & 30 & $\begin{array}{l}\text { Slightly impacted } \\
26\end{array}$ & $\begin{array}{c}\text { Nonimpacted } \\
15\end{array}$ & $\begin{array}{c}\text { Slightly impacted } \\
4.78\end{array}$ & 58 \\
\hline
\end{tabular}


Sites in the Red Clay Creek Basin (sites 26 and 27 ) were designated as moderately impacted on the basis of taxa and EPT taxa richness and were slightly impacted on the basis of HBI values (table 2, figs. 2 and 3 ). The benthic-macroinvertebrate communities at both sites contain a high percentage of "pollution tolerant" organisms, including midges, worms, and crane flies, and a very low percentage of EPT organisms (fig. 3). The dominance of "pollution tolerant" organisms along with the relatively high concentrations of nutrients indicate organic enrichment may be negatively affecting the benthic-macroinvertebrate communities in the Red Clay Creek Basin. Organic enrichment can cause increased algal blooms that decay and result in low concentrations of dissolved oxygen and poor stream-bottom habitat (U.S. Geological Survey, 1999). Heavy siltation and excessive algal growth, which decreases habitat quality, are degrading the water chemistry and physical habitat at both sites in the Red Clay Creek Basin.

Chemical data indicated steady concentrations of nutrients and major ions. Samples of stream-bottom sediment collected in the mid 1980s at both sites contained concentrations of DDT and PCBs above the threshold effect concentraton (table 3). Concentrations above the threshold effect concentration are likely to cause changes in the composition of benthic-macroinvertebrate communities (MacDonald and others, 2000). The benthicmacroinvertebrate communities in the Red Clay Creek Basin indicate major degradation possibly from organic pollution and (or) contaminated sediments. Field observations indicate that excessive algae growth and sedimentation are degrading the habitat in the basin, which also negatively affects the benthic-macroinvertebrate communities.

The three sites in the White Clay Creek Basin (sites 28, 29, and 30 ) were designated as slightly impacted on the basis of taxa richness and HBI values (table 2). All sites had benthic-macroinvertebrate communities with relatively high numbers of "pollution tolerant" organisms, including chironomids, flatworms, and crane flies. Biological metrics indicate stream quality improves in an east to west direction within the basin (fig. 3). The biological metrics at site 30 on the West Branch White Clay Creek consistently indicate better stream quality when compared to site 28 on the East Branch. Water chemistry had a similar pattern as the benthic-macroinvertebrate data. Concentrations of nutrients and major ions decreased in an east to west direction in the basin; the east branch is elevated above the west and middle branches. Site 28 is in the Borough of Avondale and receives both localized-urban runoff and agricultural runoff. Sites 29 and 30 are away (10 miles) from any direct urban effects but receive agricultural runoff.

The sites in the Red and White Clay Creek Basins had benthicmacroinvertebrate communities that indicate slightly to moderately degraded stream quality. Biological metrics indicate degraded water quality and habitat conditions are having a major negative effect on the benthic-macroinvertebrate community at both sites in the Red Clay Creek Basin. Biological metrics from the three sites in the White Clay Creek Basin also indicate degraded stream quality, but the effects are not as severe as in the Red Clay Creek Basin. Water chemistry generally was stable with slightly increasing concentrations of nitrate and major ions along with decreasing concentrations of ammonia and phosphorus. Although water chemistry was stable, the concentrations of nutrients were elevated over sites in nearby basins and field observations noted heavy siltation at sites 26,27 , and 28 . These sites receive runoff from both urban and agricultural areas including heavy mushroom farming.

Table 3. Concentrations of organochlorine insecticides and gross polychlorinated biphenyls greater than the threshold effect concentration ${ }^{1}$ from stream-bottom sediment samples collected in Red Clay Creek Basin, Chester County, Pennsylvania, 1983-97

[All concentrations are in micrograms per kilogram; - , concentration did not exceed or equal threshold effect concentration; PCB, gross polychlorinated biphenyls]

\begin{tabular}{lcccccccc}
\hline $\begin{array}{c}\text { U.S. Geological } \\
\begin{array}{c}\text { Survey station } \\
\text { identification } \\
\text { number }\end{array}\end{array}$ & $\begin{array}{c}\text { Site } \\
\text { number }\end{array}$ & Year & Chlordane & DDT & DDD & DDE & Dieldrin & PCB \\
\hline 01478120 & 28 & 1985 & - & - & 6.3 & - & - & - \\
01479680 & 27 & 1983 & - & 15 & 260 & - & 2.5 & 5,600 \\
& & 1986 & - & - & - & - & - & 1,400 \\
01479800 & 26 & 1985 & 5.0 & 61 & 36 & 22 & - & - \\
\hline
\end{tabular}

${ }^{1}$ A level of sediment contamination below which harmful effects are unlikely to be observed (MacDonald and others, 2000). 


\section{TRENDS IN BENTHIC- MACROINVERTEBRATE AND CHEMICAL DATA}

The Mann-Kendall test was used to detect trends from 1981 through 1997 in HBI values at the sites in the Red Clay Creek and White Clay Creek Basins (Helsel and Hirsch, 1997). A decreasing trend in HBI values indicates improving stream quality, and an increasing trend indicates deteriorating stream quality.

All five sites in the basins had significant increases in taxa richness and EPT taxa richness from 1981 to 1997, which is an indication of improved stream quality (fig. 4). The rising taxa richness and EPT taxa richness numbers correspond with declining concentrations of phosphorus and ammonia (fig. 4). The declining trend in concentrations of ammonia and phosphorus was detected at most sites in the Red Clay and White Clay Creek Basins although it was only statistically significant at three sites. Although the trends in taxa richness and EPT taxa richness are indicating better stream conditions in these basins, there was no statistically significant trend in HBI values because these sites are still dominated by "pollution tolerant" organisms. These sites, especially in the Red Clay Creek Basin, have stream-bottom sediments that are contaminated with pesticides, degraded habitat from sedimentation, and heavy nutrient loads.

\section{SUMMARY}

Overall, analysis of the sites in the Red Clay and White Clay Creek Basins by the U.S. Geological Survey, in cooperation with the Chester County Water Resources Authority, indicates that from 1981 to 1997, nutrient enrichment, habitat degradation, and (or) contaminated bottom sediments are limiting the benthic-macroinvertebrate communities. The conditions in the Red Clay Creek Basin are having a significant negative effect on the benthic-macroinvertebrate community. The sites in the White Clay Creek Basin also indicate degraded stream quality because of water quality and habitat conditions, but the effects are not as severe as in the Red Clay Creek Basin. Sites in both basins have increasing numbers of taxa and EPT taxa but unchanged HBI values between 1981-98, indicating improved conditions are having a limited effect on the overall benthic-macroinvertebrate community. At most sites, the nitrate concentrations have increased, but concentrations of ammonia and phosphorus have decreased over the same period.

-Andrew G. Reif

\section{REFERENCES CITED}

Bode, R.W., 1991, Quality assurance work plan for biological stream monitoring in New York State: New York Department of Environmental Conservation Technical Report, $79 \mathrm{p}$.

1993, 20 year trends in water quality of rivers and streams in New York State on the basis of macroinvertebrate data 1972-1992: New York Department of Environmental Conservation Technical Report, $196 \mathrm{p}$.

Helsel, D.R., and Hirsch, R.M., 1997, Statistical methods in water resources: New York, Elsevier Science Publishing Co., Inc., 529 p.

Hilsenhoff, W.L., 1982, Using a biotic index to evaluate water quality in streams: Wisconsin Department of Natural Resources Technical Bulletin no. 132, $22 \mathrm{p}$
Lium, B.W., 1977, Limnological studies of the major streams in Chester County, Pennsylvania: U.S. Geological Survey Open-File Report 77-462, $37 \mathrm{p}$.

MacDonald, D.D., Ingersoll, C.G., and Berger, T.A., 2000, Development and evaluation of consensus-based sediment quality guidelines for freshwater ecosystems: Archives of Environmental Contamination and Toxicology, v. 39, p. 20-31.

Reif, A.G., 1999, Physical, chemical, and biological data for selected streams in Chester County, Pennsylvania, 1981-94: U.S. Geological Survey Open-File Report 99-216, 607 p.

2000, Physical, chemical, and biological data for selected streams in Chester County, Pennsylvania, 1995-97: U.S. Geological Survey Open-File Report 00-238, $146 \mathrm{p}$

2002, Water-quality assessment and trends in biological and waterquality data from selected streams in Chester County, Pennsylvania, 1981-97: U.S. Geological Survey Water-Resources Investigations Report 02-4242, $78 \mathrm{p}$.

U.S. Geological Survey, 1999, The quality of our nation's waters-Nutrients and pesticides: U.S. Geological Survey Circular 1225, $82 \mathrm{p}$.

Weber, C.I., ed., 1973, Biological field and laboratory methods for measuring the quality of surface waters and effluents: Cincinnati, Ohio, U.S. Environmental Protection Agency, EPA-670/4-73-001.

\section{For additional information, contact:}

District Chief

U.S. Geological Survey, WRD

215 Limekiln Road

New Cumberland, PA 17070-2424

(717) 730-6913

\section{http://pa.water.usgs.gov}

Chester County Water Resources Authority

Government Services Center

601 Westtown Road

West Chester, PA 19382-4537

(610) 344-5400

http://www.chesco.org/water/index.html 